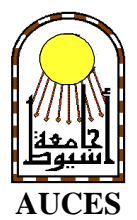

\title{
ASSESSMENT OF KNOWLEDGE AND PRACTICE OF MOTHERS TOWARD HOME ACCIDENTS AMONG CHILDREN UNDER SIX YEARS IN RURAL AREAS IN ASSIUT GOVERNORATE (2003)
}

\author{
Naglaa Saad Abd El-Aty ${ }_{* * *}^{*}$ Farag Mohammed Moftah ${ }^{*}$, \\ Hoda Diab Fahmy Ibrahim *** and Rabaa Hamed Hassanen \\ *Public Health, Faculty of Medicine and **Community Health Nursing, Faculty of Nursing,
} Assiut University

\begin{abstract}
:
Accidents are the largest single cause of death after the age of one year and are one of the most serious health problems facing the world today. They are the most common cause of hospital admission and can result in life long disability. Community health nurses are often ideally placed to offer advice about home safety. The aims of this study were to assess mothers' knowledge and practice toward home accidents among children under six years and to determine the prevalence rate of home accidents among children under six years. The present study has been carried out in Elwan and El-Masra villages in Assiut Governorate and the sample was included 200 mothers from Alwan village and 400 mothers from El-Masra village and those mothers must had children under six years. A structured questionnaire sheet was developed by the researcher to collect data $\mathrm{A}$ systematic random sampling approach was followed in this study, where every fifth home was visited in Alwan village and every tenth home was visited in El-Masra village and collection of data was performed by interviewing each mother on her home. The main results obtained from the study were as follows: most of mothers were in the age group 25 to less than 35 years and nearly all home had at least two potential environmental hazards. The present study revealed that the incidence of home accidents was (50.3\%), wounds were the commonest types of home accidents (37.4\%). And shows highly statistical difference between mother's knowledge and age and between mother's knowledge and education, about three-quarters (74.5\%) of mothers had incomplete knowledge regarding home accidents among their children. According to mothers' practice in different types of home accidents the present study indicated that the majority of mothers $\mathbf{9 3 . 2 \% \text { , }}$ 92.7\% respectively) would go to health facilities in case of scorpion stings and animal bites. The present study recommended health classes about causes of home accidents, first aid, prevention and safe housing condition for mothers at $\mathrm{MCH}$ center, in service educational program toward first aid should be established for community health nurses at rural health units and MCH center, a well-planned health education program about causes of home accidents, first aid, and prevention introduce to the curriculum at preparatory school, secondary school and university levels.
\end{abstract}




\section{INTRODUCTION:}

All children are at risk for injury because of their normal curiosity, impulsiveness and desire to master new skills and children imitate adult behavior from an early age (Ashwill and Droske, 1997 and Walker, 2002). Life cannot be risk free but utilizing household safety measures can prevent most household accidents. Most of children feel safe and secure in their home, yet unfortunately at home is where many injuries and deaths occur (Alper, 2003). According to Allender and Spradley, (2001) accidents are unforeseen and unfortunate happening. Amore precise term that refers to any injury that results from unintended exposure to physical agents including heat, mechanical energy, chemicals or electricity. Home accidents differ from country to another due to many factors such as economical and cultural factors. The largest number of accidents happens in the living room, however the most serious accidents happen in the kitchen (Hadd, 1994 and Hogg, 1996). The main causes of accidents in the home are falls, fires and burns, drowning, suffocation, choking, poisoning and cuts and lacerations (Walker, 2002 and Bradley, 1987). Accidents are one of the five leading causes of death in industrialized and developing countries (Goldman, 1995, Stanphope and Lancaster, 1996). Also accident is the leading cause of death and is a major reason for hospital admission and long term of disability in this age group from 3 to 5 years (Robinson and Roberton, 2003). Injuries arising from home accidents are increasing community health problems (Sattin et al., 1998). According to National Safe Kids Campaign (2000) unintentional injury remains the leading cause of death among children ages 14 and under in United States. Also $40 \%$ of deaths and $50 \%$ of non-fatal unintentional injuries occur in and around the home. Accidents in Egypt are a major cause of morbidity and mortality in children below 5 years and children within 14 years. In Egypt in 1998, the overall prevalence of injuries in indoor home environment were 72.5\% among children below 5 years (Amin $e t$ al., 1998). Also in El- Assara village, in Assiut Governorate in 1998 the incidence of home accidents among children age $(0-<18)$ year was 59\% (Hamza,2000).

Prevention and control of home accidents among children has been recently a target and very important area for health promotion (Abd El Wahed, et al., 2000). The community health nurse will try to ensure that people know how to prevent accidents. When home visiting done accidents hazards will be identified and advice given to correct them. The dangers to young children will be pointed out, mothers and fathers will be informed of their responsibility to make their home a safe place and to teach their children how to live safely in the environment (Bradley, 1987 and 1997). Also community health nurse is responsible to prevent injuries in their communities, at homes, schools, and work places (Hitchcock, 1999).

\section{Aim of the study:}

1- To assess the mother's knowledge and practices toward home accidents among children under six years.

2- To measure prevalence rate of home accidents among children under six years in rural area in Assiut Governorate.

\section{MATERIAL AND METHODS:}

\section{Material :}

1-Setting of the study: The study was conducted at two villages in Assiut Governorate, the first village is called El-Masra village, and it locates at East of the Nile. The second village is 
called Alwan village, and it locates at West of the Nile.

2-Sample: The sample size was 600 mothers have children under six years from two villages. In which 400 mothers were drawn from ElMasra village this number was drawn by a systematic random approach of visiting every tenth house. Two hundreds mothers were drawn from Alwan village this number was drawn by a systematic random approach of visiting every fifth house in the village. Those mothers were interviewed in their homes through home visits.

3-Tools: A structured interview sheet was developed based on relevant literature in order to assess knowledge and practice of mothers toward home accidents among children under six years.

A-The first questionnaire was about the family, it includes socio-demographic characteristics as mother's age, education, occupation and father's age, education and occupation, and number of children under six years.

B-The second questionnaire was about home environment, these questions were concerned with the housing condition and accidents contributing factors as presence of windows shield, presence of balconies rails, presence of stairs rails, presence of electrical outlets, type of fans, how storage drinking water, presence of sewage, type of cooker and oven used, where keeping matches and sharp objects, storage medication and toxic house holds.

C-The third questionnaire about mother's knowledge toward causes of home accidents among children under six years, occurrence of home accidents and its type.

D-The fourth questionnaire about mother's practices or immediate first aid measures that she made it to her child if he exposed to any type of home accidents.

\section{Methods:}

1-Administrative design: The official letter from Faculty of Nursing in Assiut Govern orate was prepared and delivered to Undersecretary of Health in Assiut Health Directorate for the approval for the collection of data from two villages.

2-Pilot study: A pilot study was performed to evaluate the questionnaire validity. It was carried out on a sample of 60 mothers $(10 \%$ from the sample). This sample was excluded from the total sample. Then the necessary modifications in the sheet were done according to the results of the pilot study.

3-Data collection technique: Data was collected through home visits by interviewing every mother individually at her home to assess her knowledge and practices toward home accidents and to assess home environment. The average number interviewed was 12-15 case per-day and average time taken for completing each sheet was around 15-20 minutes, this was depending on the response of the mothers. The researcher had explained the purpose of this study and it's importance for each mother.

4-Statistical design: Data were collected over a period of four months starting from July to October 2003. Then the collected data were tabulated and analyzed using computer. The obtained data were analyzed and tabulated, descriptive statistics as frequencies, percentage, mean and standard deviation were calculated using computer. Cross tabulation and chisquare test were also used and $P$ value less than or equal 0.05 were considered as statistically significant. 


\section{RESULTS:}

Table (1) shows that less than half $(46.3 \%)$ of mother's age was ranged between (25-34) years old with mean of $\mathbf{2 8 . 2 3}$ and std. Deviation 6.91, and more than half of mothers $(55.7 \%)$ were illiterate, while only $(\mathbf{2 . 0 \%})$ of them had university education. This table also was clear that the majority of the mothers $(94.5 \%)$ were not working for cash. According to the family size this table shows that $(\mathbf{2 7 . 5 \%})$ of families had seven or more members and $(45.0 \%)$ of the mothers had two children under six years old with mean 1.8 and std. Deviation 0.71.

Table (2) shows the presence of unsafe environmental characteristics present in the studied homes. The most prevalence of unsafe environmental characteristics $(81.1 \%, 66.7 \%$ and $40.0 \%$ respectively) was use of oven, unsafe storage of medication and unsafe roof rails.

Figure (1) Illustrated that incidence rate of home accidents among children under six years in El-Masra and Alwan village in the year 2003 as perceived by their mothers was $(50.3 \%)$, and also Figure (2) shows that the commonest type of home accidents $(37.4 \%)$ was wounds followed by burns $(20.8 \%)$ and the lowest type $(0.3 \%)$ was drowning and scorpion stings respectively.

Figure (3) Illustrated mother's knowledge regarding causes of home accidents, it was found that $(\mathbf{7 4 . 5 \% )}$ of mothers reported incomplete knowledge and $(\mathbf{1 4 . 5 \%})$ of mothers were do not know the causes of home accidents, while (11.0) of them reported complete knowledge.

Table (3) shows relation between mother's age, education and her knowledge regarding causes of home accidents. It was found that $(55.5 \%)$ of mothers who their age ranged from 45-55 years were do not know causes of home accidents, while $(16.7 \%)$ of mothers who their

Table (1): Distribution of the studied sample according to socio-demographic characteristics age ranged from 45-55 years reported complete knowledge. There are highly significant differences between mother's age and her knowledge regarding home accidents $(\mathbf{p}=\mathbf{0 . 0 0 1})$. Regarding relation between mother's education and her knowledge, this table showed that $\mathbf{( 1 9 . 6 \% )}$ of mothers who were do not know the causes of home accidents were illiterate, while $(\mathbf{1 4 . 3 \%})$ of them who reported complete knowledge were read and write. There is highly significant difference between mother's education and her knowledge regarding causes of home accidents $(p=0.0001)$.

Table (4) Shows that $(68.5 \%, 32.3 \%, 27.5 \%$, $68.2 \%$ respectively) of mothers went to health facilities or hospital in case of fracture, wound, suffocation and choking and (15.5\%) of them used traditional methods in case of fracture such as folklore methods as massage with oil or hot water, went to the bone fixer for making cataplasm from egg and linen or from egg and lentils or from bran. Also it was found that $\mathbf{2 0 . 0 \%}$ ) of mothers used traditional methods in case of wound such as they can use kerosene or tincture of iodine or just wash the wound and tie it, while in case of bleeding $(38.0 \%)$ of them applied pressure down hard on bleeding site, and $(37.0 \%)$ of them used traditional methods such as using alcohol, kerosene and dry tea or dry coffee.

Also table (4) Illustrated that $(15.3 \%$ and $\mathbf{2 6 . 8 \%}$ respectively) of mothers used traditional methods in case of suffocation and choking such as applying pressure on child's chest or smelling affected child perfume in case of suffocation, and giving child cotton with molasses or she will eat the child bread without any thing or applying pressure on child's back in case of choking. 


\begin{tabular}{|c|c|c|}
\hline Items & No. $=600$ & Percent \\
\hline $\begin{array}{l}\text { Mother's age: } \\
\text { 15- } \\
\text { 25- } \\
35- \\
45 \text { - } 55\end{array}$ & $\begin{array}{c}191 \\
278 \\
113 \\
18\end{array}$ & $\begin{array}{c}31.8 \\
46.3 \\
18.9 \\
3.0\end{array}$ \\
\hline Mean \pm SD & \multicolumn{2}{|c|}{$28.23 \pm 6.91$} \\
\hline $\begin{array}{l}\text { Mother's education: } \\
\text { Illiterate } \\
\text { Read \&write } \\
\text { Preparatory education } \\
\text { Secondary education } \\
\text { University education } \\
\end{array}$ & \begin{tabular}{c|}
334 \\
63 \\
48 \\
143 \\
12 \\
\end{tabular} & \begin{tabular}{c|}
55.7 \\
10.5 \\
8.0 \\
23.8 \\
2.0 \\
\end{tabular} \\
\hline $\begin{array}{l}\text { Mother's job: } \\
\text { Not working for cash } \\
\text { Working for cash } \\
\end{array}$ & $\begin{array}{c}567 \\
33 \\
\end{array}$ & $\begin{array}{c}94.5 \\
5.5\end{array}$ \\
\hline $\begin{array}{l}\text { Family size: } \\
\text { Three members } \\
\text { Four members } \\
\text { Five members } \\
\text { Six members } \\
\text { Seven or more members } \\
\end{array}$ & \begin{tabular}{c|}
93 \\
117 \\
121 \\
104 \\
165 \\
\end{tabular} & $\begin{array}{l}15.5 \\
19.5 \\
20.2 \\
17.3 \\
27.5 \\
\end{array}$ \\
\hline $\begin{array}{l}\text { No of children under six years: } \\
\text { One child per mother } \\
\text { Two children per mother } \\
\text { Three and more children per mother }\end{array}$ & $\begin{array}{c}237 \\
270 \\
93\end{array}$ & $\begin{array}{l}39.5 \\
45.0 \\
15.5\end{array}$ \\
\hline Mean \pm SD & \multicolumn{2}{|c|}{$1.8 \pm 0.71$} \\
\hline
\end{tabular}

Table (2): Distribution of home according to presence of unsafe environmental characteristics

\begin{tabular}{||l|c|c||}
\hline \multicolumn{1}{|c|}{ Unsafe environmental characteristics } & No. = 600 & Percent \\
\hline Balconies rails & 34 & 5.7 \\
Stairs rails & 151 & 25.2 \\
Absent of windows shield & 46 & 7.7 \\
Roof rails & 240 & 40.0 \\
Electric outlets & 85 & 14.2 \\
Storage of drinking water & 17 & 2.8 \\
Placing of office and floor fan & 65 & 10.8 \\
Storage of sharp objects & 81 & 13.5 \\
Placing of kerosene stove & 130 & 21.7 \\
Storage of kerosene & 130 & 21.7 \\
Use of oven & 491 & 81.8 \\
Storage of cleaning agents & 48 & 8.0 \\
Storage of medication & 400 & 66.7 \\
\hline
\end{tabular}

*There is more than one of environmental hazard at home. 
Table (3): Relation between mother's age, education and her knowledge regarding causes of home accidents

\begin{tabular}{|c|c|c|c|c|c|c|c|c|}
\hline \multirow{3}{*}{ Items } & \multicolumn{8}{|c|}{ Mother's knowledge } \\
\hline & \multicolumn{2}{|c|}{ Do not know } & \multicolumn{2}{|c|}{$\begin{array}{l}\text { Incomplete } \\
\text { knowledge }\end{array}$} & \multicolumn{2}{|c|}{$\begin{array}{c}\text { Complete } \\
\text { knowledge }\end{array}$} & \multirow[t]{2}{*}{ Total } & \multirow[t]{2}{*}{ P-value } \\
\hline & No & $\%$ & No & $\%$ & No & $\%$ & & \\
\hline \multicolumn{9}{|l|}{ Mother's age } \\
\hline $15-$ & 30 & 15.7 & 143 & 74.9 & 18 & 9.4 & 191 & \multirow{5}{*}{$0.001 *$} \\
\hline 25- & 29 & 10.4 & 213 & 76.6 & 36 & 12.9 & 278 & \\
\hline 35- & 18 & 15.9 & 86 & 76.1 & 9 & 8.0 & 113 & \\
\hline $45-55$ & 10 & 55.5 & 5 & 27.8 & 3 & 16.7 & 18 & \\
\hline Total & 87 & 100.0 & 447 & 100.0 & 66 & 100.0 & 600 & \\
\hline \multicolumn{9}{|l|}{ Mother's education } \\
\hline Illiterate & 65 & 19.6 & 236 & 70.7 & 33 & 9.9 & 334 & \multirow{6}{*}{$0.0001 *$} \\
\hline Read \&write & 8 & 12.7 & 46 & 73.0 & 9 & 14.3 & 63 & \\
\hline Prep & 7 & 14.5 & 38 & 79.2 & 3 & 6.3 & 48 & \\
\hline Secondary & 6 & 4.2 & 117 & 81.8 & 20 & 14.0 & 143 & \\
\hline University & 1 & 8.3 & 10 & 83.4 & 1 & 8.3 & 12 & \\
\hline Total & 87 & 100.0 & 447 & 100.0 & 66 & 100.0 & 600 & \\
\hline
\end{tabular}

*Statistical significant difference.

Ns. Not significant difference.

Table (4): Distribution of mothers practices in case of fracture, wound, bleeding, suffocation, and choking

\begin{tabular}{|c|c|c|}
\hline Mothers practice & No. $=600$ & Percent \\
\hline \multicolumn{3}{|l|}{ Fracture: } \\
\hline Go to health facilities & 411 & 68.5 \\
\hline Counsel relatives & 26 & 4.3 \\
\hline Traditional methods & 93 & 15.5 \\
\hline More than one approach & 70 & 11.7 \\
\hline \multicolumn{3}{|l|}{ Wound: } \\
\hline Go to hospital & 194 & 32.3 \\
\hline Uses of cotton, gauze and antiseptic solutions & 259 & 43.2 \\
\hline Traditional methods & 120 & 20.0 \\
\hline More than one approach & 27 & 4.5 \\
\hline \multicolumn{3}{|l|}{ Bleeding: } \\
\hline Elevated affected part & 9 & 1.5 \\
\hline Apply pressure on bleeding site & 228 & 38.0 \\
\hline Putting under running water & 78 & 13.0 \\
\hline Traditional methods & 222 & 37.0 \\
\hline More than one approach & 63 & 10.5 \\
\hline \multicolumn{3}{|l|}{ Suffocation: } \\
\hline Close gas tube & 49 & 8.2 \\
\hline Increase ventilation & 220 & 36.7 \\
\hline Go to hospital & 165 & 27.5 \\
\hline Traditional methods & 92 & 15.3 \\
\hline More than one approach & 74 & 12.3 \\
\hline \multicolumn{3}{|l|}{ Choking: } \\
\hline Go to hospital & 409 & 68.2 \\
\hline Counsel relatives & 9 & 1.5 \\
\hline Traditional methods & 161 & 26.8 \\
\hline More than one approach & 21 & 3.5 \\
\hline
\end{tabular}


Table (5) Shows that $(\mathbf{4 0 . 9 \% )}$ of mothers will elevate child from his legs and down his head on floor in case of drowning, while $(29.8 \%$ ) of them will used traditional methods such as applying pressure on the child's abdomen or will give the child water with salt in case of drowning. Also it was found that $(56.8 \%, 93.2 \%$, $\mathbf{9 2 . 6 \%}$ and $\mathbf{1 9 . 2 \%}$ respectively) of mothers went to health facilities in case of poisoning, scorpion stings, animal bites and burn. While (33.7\%, $1.3 \%, 1.7 \%$ and $24.2 \%$ respectively) of them will used traditional methods such as giving child water with lemon, milk, egg with milk or water with salt or polling mint in case of poisoning and egg with oil, egg with salt, only oil or only egg or used shaving cream in case of burn. This table also was clear that $(\mathbf{4 7 . 3 \%})$ of mothers turned off the power first in case of electrical accidents and $(32.7 \%)$ of them pulled child with piece of wool or touch the child without any disconnection. Also this table shows that that $(35.3 \%)$ of mothers covered electric outlets with adhesive tape.

Figure (4) illustrated that the vast majority of the mothers $(93.2 \%$ and $92.7 \%)$ went to health facilities in case of scorpion stings and animal bites.

Table (5): Distribution of mothers practices in case of drowning, poisoning, scorpion stings, animal bites, burn and electrical accidents

\begin{tabular}{|c|c|c|}
\hline Mothers practice & No. $=600$ & Percent \\
\hline \multicolumn{3}{|l|}{ Drowning: } \\
\hline Increase air & 2 & 0.3 \\
\hline Elevate child's legs and down his head & 245 & 40.9 \\
\hline Go to hospital & 158 & 26.3 \\
\hline Traditional methods & 179 & 29.8 \\
\hline More than one approach & 16 & 2.7 \\
\hline \multicolumn{3}{|l|}{ Poisoning: } \\
\hline | Go to health facilities & 341 & 56.8 \\
\hline Traditional method & 202 & 33.7 \\
\hline More than one approach & 57 & 9.5 \\
\hline \multicolumn{3}{|l|}{ Scorpion stings: } \\
\hline Go to health facilities & 559 & 93.2 \\
\hline Tie the affected part & 3 & 0.5 \\
\hline Traditional methods & 8 & 1.3 \\
\hline More than one approach & 30 & 5.0 \\
\hline \multicolumn{3}{|l|}{ Animal bites: } \\
\hline Go to health facilities & 556 & 92.6 \\
\hline Traditional method & 10 & 1.7 \\
\hline Go to barber & 4 & 0.7 \\
\hline More than one approach & 30 & 5.0 \\
\hline \multicolumn{3}{|l|}{ Burn: } \\
\hline Go to health facilities & 115 & 19.2 \\
\hline Ice or cold water & 203 & 33.8 \\
\hline Traditional methods & 145 & 24.2 \\
\hline More than one approach & 137 & 22.8 \\
\hline \multicolumn{3}{|l|}{ Electrical accidents: } \\
\hline Turning off the power first & 284 & 47.3 \\
\hline Pull child with piece of wood & 84 & 14.0 \\
\hline Pull child with piece of wool & 196 & 32.7 \\
\hline More than one approach & 36 & 6.0 \\
\hline \multicolumn{3}{|l|}{ Mother action to prevent children from playing on lower electric outlets: $\mathbf{N}=85$} \\
\hline No thing & 55 & 64.7 \\
\hline Adhesive tape on electric outlets & 30 & 35.3 \\
\hline
\end{tabular}


Ass. Univ. Bull. Environ. Res. Vol. 8 No. 2, October 2005

$-18-$ 
Table (6) clears that the relation between mother's education and her practice in case of fracture wound, bleeding, suffocation, choking and drowning. It was found that about three quarters $\mathbf{7 6 . 2 \%}$ and $\mathbf{7 4 . 8 \%}$ respectively) of mothers who were read and write and had secondary education went to health facilities in case of fracture. Regarding relation between mother's education and her practice in case of wound this table was clear that $(\mathbf{4 2 . 2 \% )}$ of mothers who were illiterate went to health facilities in case of wound, and three quarters $\mathbf{7 5 . 0 \% )}$ of them used cotton, gauze and antiseptic solution were had university education. There is highly statistical significant difference between mother's education and her practice in case of wound $(p=0.000)$.

Table (6) also showed that $(8.3 \%)$ of mothers who had university education elevated affected part in case of bleeding, while more than two fifth $\mathbf{( 4 2 . 9 \% )}$ of mothers who were read \& write used traditional methods. There is statistical significant difference between mother's education and her practice in case of bleeding $(\mathbf{p}=\mathbf{0 . 0 2})$. Concerning case of suffocation, it was found that one half $(50.0 \%)$ of mothers who had university education increase ventilation, while less than one-third $\mathbf{3 0 . 8 \% )}$ of them who illiterate were went to hospital. There is highly statistical significant difference between mother's education and her practice in case of suffocation $(p=0.000)$.

This table also shows that the vast majority of mothers $(91.7 \%)$ who had university education went to health facilities in case of choking. There is no statistical significant difference between mother's education and her practice ( $p=0.086)$. Regarding case of drowning, shows that $(46.1 \%)$ of mothers who had secondary education elevated child's legs and down his head on the floor and $(\mathbf{4 1 . 3 \%})$ of them who were read \&write went to hospital in case of drowning. There is statistical significant difference between mother's education and her practice in case of drowning $(p=0.006)$. 
Table (6): Relation between mother's education and her practice in case of fracture, wound, bleeding, suffocation, choking and drowning

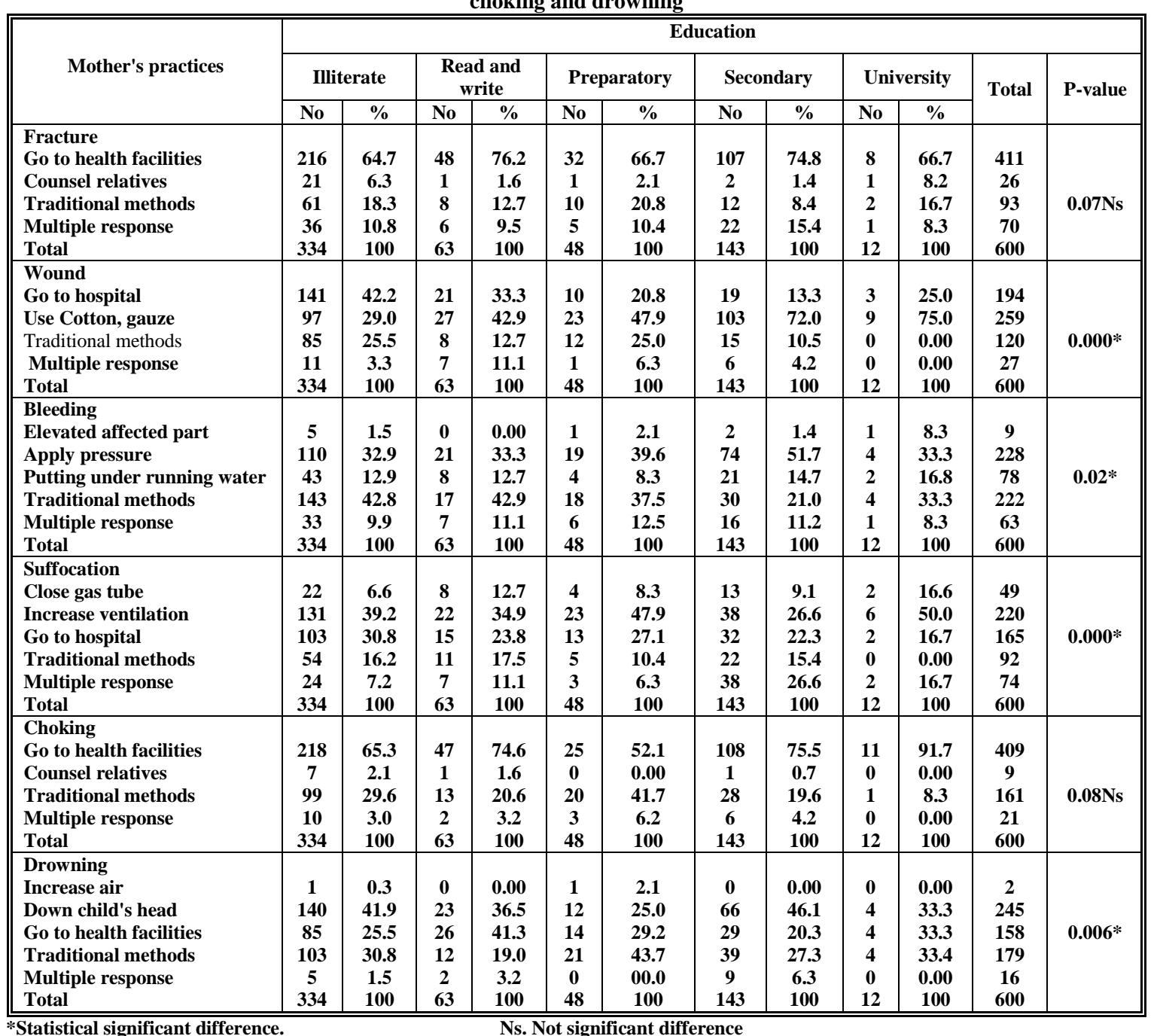

Table (7) illustrated that relation between mother's education and her practice in case of poisoning, scorpion stings, animal bites, burn and electrical accidents. It was found that $(58.3 \%, 58.1 \%$ and $41.7 \%$ respectively) of mothers who had preparatory education, illiterate and had university education went to health facilities in case of poisoning.

Table (7) also show that all mothers who had university education and the vast majority (95.8\%) of them who had secondary education were went to health facilities in case of scorpion stings. As regarding animal bites it was found that all of mothers who had university education went to health facilities and $(\mathbf{9 0 . 4 \%})$ of them who were illiterate went to health facilities.

According to the relation between mother's education and her practice in case of burn, It was found that more than one quarter (25.9\%) of mothers who had secondary education went to health facilities, and $(28.1 \%)$ of them who were illiterate used traditional methods. There is significant difference between mother's 
education and her practice in case of burn ( $p$ $=0.012$ ).

Also table (7) clear that $(\mathbf{5 8 . 7 \%})$ of mothers who were read and write were turning off power first in case of electrical accidents, while (25.0\% and $\mathbf{1 1 . 1 \%}$ respectively) of mothers who had university education and were read and write were pull child with pieces of wood. There is highly statistical significant difference between mother's educational and her practice in case of electrical accidents $(p=0.000)$.

Table (7): Relation between mother's education and her practice in case of poisoning, scorpion stings, animal bites, burn and electrical accident.

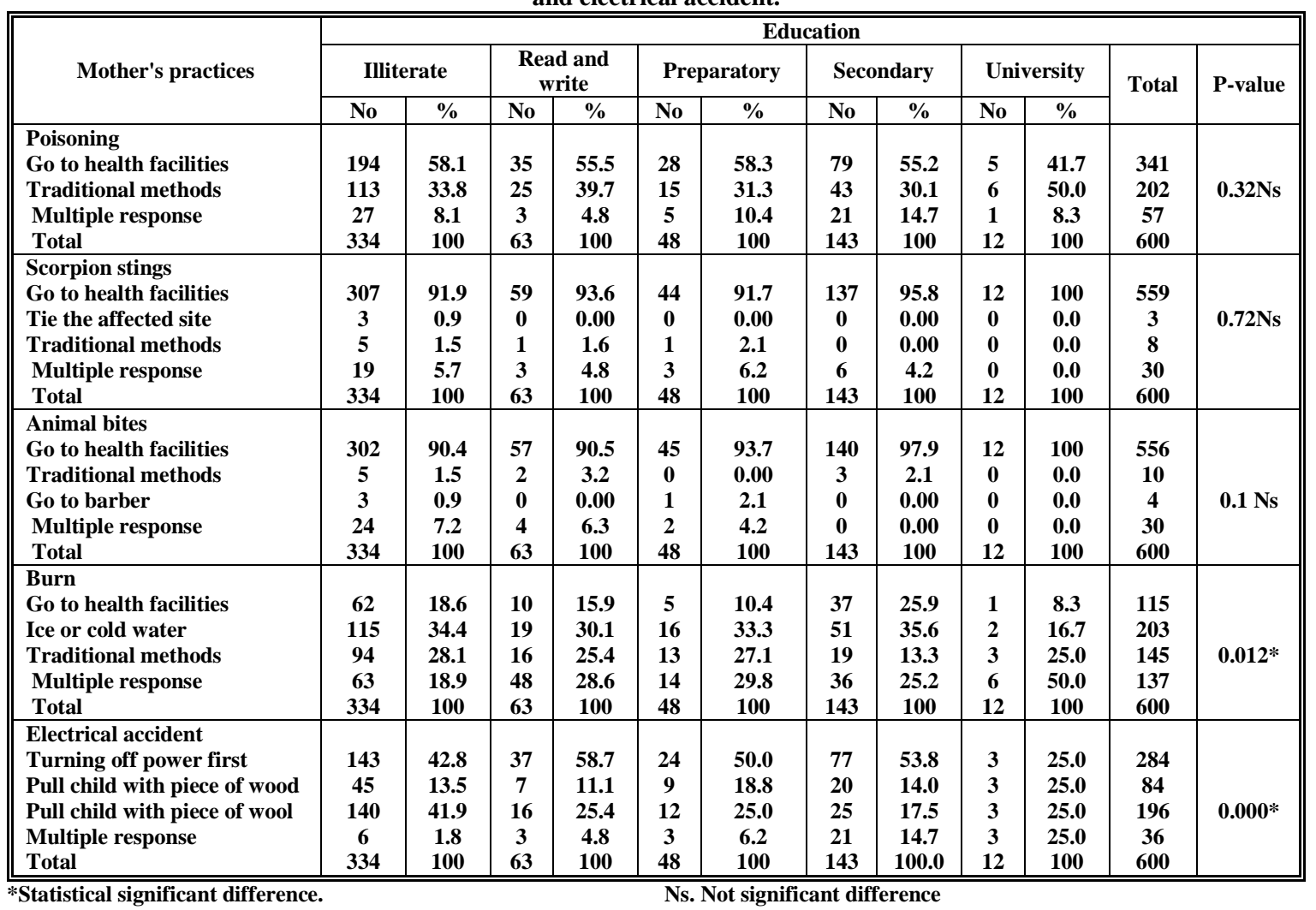

\section{DISCUSSION:}

The first five years are considered a critical period of life where the child learns to investigate and react with his surrounding and they move curious move too much (Wong et al., 1999). Preschool children accidents are an important cause of injuries and deaths so that accidents among children under the age of five years are important problems that need active reduction intervention (Shatanawi, 1992)
Accidents are the largest single cause of death after the age of one year and are one of the most serious health problems facing the world today. They are the most common cause of hospital admission and can result in life long disability (Soori and Naghavi, 1999). Mother's knowledge, attitude and practice are relevant variables and are considered important factors in planning an educational program for accidents prevention so many accidents could be less serious if parents with children know what 
to do as soon as they occur (Ibrahim, 1991). So the aim of the present study was To assess the mother's knowledge and practices toward home accidents among children under six years and to measure prevalence rate of home accidents among children under six years in rural area in Assiut Governorate.

The present study revealed that the vast majority of mothers $(94.5 \%)$ were not working for cash. Abd El-Rhaman, (1998) mentioned that $(54.0 \%)$ of mothers in his sample were housewives and the home accidents rate was high among their children. According to housing condition Amine et al., (1998) and Ahmed, (1989) mentioned that living condition in rural areas attributed to environmental factors such as cooking over open fires lead to burns and scalds. Badly built houses and poor maintenance such as stairs without railings might cause falls. The present study revealed that nearly all homes had at least two environmental hazards. The most prevalence of hazards was usage of oven, unsafe storage of medication, unsafe roof rails, unsafe storage of sharp objects, unsafe placing of kerosene stove and unsafe stairs rails. The present study is agreed with another study on assessment of home environmental risk factors regarding accidents among preschool children conducted by Helmy et al., (2002) mentioned that nearly all home of the studied sample had at least two potential hazards and the most prevalence hazards were storage crops, unsafe toys, rearing of animals and use of wood stove.

Regarding to exposure to home accidents the present study revealed that the prevalence of home accidents among children in El-Masra and Alwan village in the year 2003 was $(50.3 \%)$. This finding is in agreement with Ibrahim, (2004) who revealed that the incidence rates of accidents per thousand were $(60.0 \%)$ in year 1999, $(43.9 \%)$ in year 2000 and $(42.1 \%)$ in year
2001. The present study is in disagreement with another pervious studies done by Awad, (1990) and Nosseir, et al., (1990) who mentioned that the rate of accidents among children aged (1-4) years were $(\mathbf{2 4 . 0 \%})$ and the over all accident rate was $(13.0 \%)$ among the preschool children attending the Maternal Child Health Care Centers of Alexandria. Also the present study is in disagreement with another study done in a rural community in Qalubeya Governorate revealed that the over all prevalence of injuries indoor home environment were $\mathbf{( 7 2 . 6 \% )}$ among children below five years (Amin, et al., 1998). The difference between these studies and the present study may be due to the difference in the age of the studied children, different methodology, calculated period prevalence, study area and habits of rural area.

As regarding types of home accidents, the present study indicates that wounds were the most common accidents among studied children $(37.4 \%)$. Many studies had been conducted in Assiut Governorate by Ibrahim, (2004), and Helmy, (2002) revealed that wounds represented (66.2\%, and $43.4 \%$ respectively) among studied children. These findings were higher than the present study because of different methodology and different age structure. Other studies conducted by Hamza (2000), El-sabakhy, et al., (1981), Sadek and Ahmed (1986) and Nosseir, et al., (1990) reported that wounds accounted for (26.3\%, $15.7 \%, 14.0 \%$ and $14.9 \%$ respectively) these findings were lower than the present study as these studies had been carried in communities of different age group and by different methodology. The present study is in agreement with Helmy, et al., (2002), Nossier et al., (1990) and El-Gendawy, (1978) who mentioned that burns represented (20.2, $22.6 \%$ and $20.4 \%$ respectively)of injuries among preschool children. The present result is in disagreement with Ibrahim, (2004), Hamza 
(2000) Amin, et al., (1998) and Laffoy (1997) who reported that burns are represent $(8.2 \%$, $15.4 \%, 10.5 \%$ and $13.0 \%$ respectively) of all injuries. These findings were lower than the present study because these studies had been carried by different methodology.

According to fractures the present study recorded that fractures represent $(\mathbf{1 5 . 8 \%})$ of the total child injuries The present study is in disagreement with Helmy et al., (2002), Hassan and El-Sheikh (1996) and Ibrahim, (1991) who reported that fractures accounted for $(40.1 \%, 29.0 \%$ and $30.0 \%$ respectively). These findings were higher than the present study this difference may be due to different age structure and different methodology. The present study is in agreement with the studies conducted in Egypt by Ibrahim (2004), and Kamel et al., (2003), who reported that fractures accounted for $(14.7 \%$ and $14.5 \%$ respectively). Concerning choking the present study indicates that choking accounted for $(8.6 \%)$ of the total child accidents. The present study is in disagreement with Helmy et al., (2002) who reported that choking caused $(19.1 \%)$ of accidents among preschool children. The present study indicates that poisoning accounted for $\mathbf{( 7 . 6 \% )}$ of the total injuries among studied children. This result is in agreement with another studies conducted by, Ibrahim (2004), Helmy et al., (2002), Sadek and Ahmed (1986), who reported that poisoning cases represented $(10.9 \%, 9.6 \%$ and $7.9 \%$, respectively) of total injuries among children.

According to mother's knowledge regarding home accidents the present study revealed that about three-quarters $\mathbf{( 7 4 . 5 \% )}$ ) of mothers were cited incomplete answer regarding causes of home accidents. This can attributed to the facts that the majority of mothers were illiterate or just had basic education. This finding agreed with Helmy et al., (2002) who found that the total score of inadequate knowledge among mothers were (79.03\%). Another study conducted by Ibrahim, (1991) revealed that more than half of the mothers $(56.0 \%)$ in the accidents group did not know any thing about home accidents to which their children might be exposed, while $(\mathbf{7 8 . 0 \%})$ of them believe that accidents is preordained. According to relation between mother's age and their knowledge regarding causes of home accidents the present study recorded that $(\mathbf{1 6 . 6 \%})$ of mothers aged 45-55 years were had higher percent of complete answer this can be due to their increased awareness and experience through life in child rearing. This result agreed with Helmy et al., (2002) who revealed that mothers aged 30 years to less than 40 years had higher scores of knowledge regarding home accidents. Regarding to relation between mother's education and their knowledge regarding causes of home accidents among their children the present study found that $(\mathbf{1 9 . 5 \%})$ of mothers who cited wrong answer were illiterate, and $(83.4 \%)$ of mothers who cited incomplete answer were had university education. The present study agreed with Helmy et al., (2002) who reported that illiterate mothers failed to obtain knowledge regarding home accidents.

Mother's practices in different types of home accidents: In case of fracture the present study recorded that more than two thirds of mothers $(68.5 \%)$ stated that they would go to the health facilities, and $(15.5 \%)$ of mothers would use traditional methods. This finding agreed with Ibrahim, (1991) who mentioned that $(\mathbf{8 0 . 0 \%})$ of mothers in accidents group and $(44.0 \%)$ of non accidents group indicated that they would go to hospital in case of fracture, while $\mathbf{( 1 0 . 0 \%}$ and $\mathbf{8 . 0 \%}$ of mothers in accident group and non accidents group respectively indicated that they would go to bone fixer in case of fracture. 
In case of wound the present study indicated that more than two fifth $(\mathbf{4 3 . 2 \%})$ of mothers said that they would use cotton, gauze and antiseptic solution and about one third $(32.3 \%)$ of mothers said that they would go to hospital, while $(20.0 \%)$ of them said that they would use traditional methods. This finding is agreed with Ibrahim, (1991) who reported that the majority of mothers $(\mathbf{8 6 . 0 \%}$ and $\mathbf{7 4 . 0 \%}$ respectively) in never accident group and accident group would cotton and antiseptic solution and the rest of the sample said that they can use coffee or oven's ash. This is can be explained on the bases of wound accidents are common and mothers know how to deal with them. As regarding to relation between mother's education and their practice the present study recorded that $\mathbf{( 4 2 . 2 \% )}$ of mothers who told they would go to hospital were illiterate, and most of mothers $\mathbf{( 7 5 . 0 \% )}$ ) who said they would use cotton, gauze and antiseptic solution were had university education. This can be attributed to the fact that when the mothers are more educated they will used proper first aid and become more aware about proper first aid. As regarding mother's practices in case of burns, the present study showed that $(\mathbf{3 3 . 8 \%})$ of mothers said that they would use ice or cold water in case of burn and (24.2\%) of mothers said that they would use traditional methods, while $(\mathbf{1 9 . 2 \%})$ of them said that they would go to health facilities. This finding disagreed with Ibrahim, (1991) who reported that $(54.0 \%)$ of mothers in accidents group mentioned that they would go to hospital, while $(\mathbf{4 8 . 0 \%})$ of them in non accidents group they could use traditional methods. According mother's practices in case of poisoning, the present study revealed that more than half of mothers said that they would go to health facilities in case of poisoning and one third of mothers said that they would use traditional methods. Ibrahim, (1991) mentioned that $(32.0 \%)$ of mothers in accidents group said that they would go to hospital, while $(\mathbf{4 8 . 0 \%})$ of mothers in non-accidents group said that they would go to hospital in case of poisoning. Baker, (1980) and Cook et al., (1991) reported that mothers should go quickly to hospital and if the hospital is far from home give child Ipecac to induce vomiting after prescription from the physician.

\section{CONCLUSION:}

From the pervious results, one can conclude that: mothers' knowledge regarding home accidents among children under six years were incomplete also mothers' age and education were variables significantly in relation with mothers' knowledge regarding home accidents.

Mothers' practice toward home accidents among children under six years were deficient, also mothers' education have effect on mothers' practice in different types of home accidents, the present study revealed that well educated mothers will use the proper first aid, while illiterate mothers tends to use traditional method. There is need for educational program for parents especially mothers with young children about home accidents and how to manage it if occur.

\section{RECOMMENDATIONS:}

1-Health classes about causes of home accidents, first aid, and prevention for mothers should be held in $\mathrm{M} \mathrm{C} \mathrm{H} \mathrm{C.}$

2-Health education program for mothers about safe housing condition should be held in MCHC.

3-In service educational program toward first aid should be established for community health nurses at rural health units and $\mathrm{MCH}$ centers . 
4-A well-planned health education program about causes of home accidents, first aid, and prevention into the curriculum at preparatory, secondary school and university levels.

5-Community awareness campaigns should be developed to help reduce home accidents and how to provide appropriate first aid in case of accidents.

\section{REFERENCES:}

Abd El -Rahman L, (1998): "Deaths due to home accidents in Alexandria". The Egyptian Journal of Occupational Medicine, 22 (4): 83-89.

Abd El-Wahed $M$ A, Mitwally H H, \& Mahmoud N M, (2000): "Preventive program for home injuries among rural children in Egypt and Oman". Alexandria journal of pediatrics, 14 (1), pp. 65-71.

Ahmed H, (1989): "Study to assess safety measures adopted at home to prevent poisoning among children under five years of age". Master thesis Public Health Nursing. Higher Institute of Nursing, University of Alexandria.

Allender $\mathbf{J}$ A \&Spradley $\mathrm{B} \quad \mathrm{W}$, (2001). "Community health nursing concepts and practice", $\quad\left(5^{\text {th }}\right.$ ed. $)$ Lippincott, Philadelphia, pp. 540-541.

Alper J,(2003): "Home safe home, Healthology", Inc. www.hsh.Com

Amin M, Abd El-Moneim M,\& Hafez A, (1998): "Epidemiological study of preschool injuries in rural community", Qalubeya Governorate. The Egyptian Journal of community Medicine, 16 (1): 31-41.

Ashwill JW \& Droske S C, (1997): "Nursing care of children principal and practice", W.B. Saunders company, Philadelphia, pp. 256-296.
Awad N N S, (1990): "An epidemiology study of morbidity and mortality among children aged 1-4 years in Alexandria". Thesis for Dr PH, High Institute of public Health, Alexandria University. Quoted from Injury Surveillance in developing countries, 1993.

Baker S R, (1980): "Public health; M. D. U. S. A. pediatrics"; Experta Medica, Vol. 35, issue 4.

Bradley F M, (1987): "Community health for student nurses", home safety, accidents prevention, W.B. Saunders company, Philadelphia, pp. 430-437.

Bradley F M, (1997): "Community health for student nursing", ( $1^{\text {st }}$ ed.), W B. Saunders company, Philadelphia, pp. 430-439.

Cook fair J M, (1991): "Nursing process and practice in the community", St. Louis. Mosby, Yearbook, pp. 187-205.

El-Gendawy H A S, (1978): "Exploration of the predominant external causes of burns attended to the major medical centers in Assiut". Thesis for M P H, Assiut University

El-Sebakh H, Fahmi S I, Tantawy A S, \& Moustafa K, (1981): "Reported accidents of university students in Alexandria University health services". Bulletin of High Institute of Public Health in Alexandria, 9: 353-366.

Goldman L, (1995): "Case studies of environmental risks to children. Environmental protection Agency". Future-Child, 5 (2): 27-33.

Hadd F, (1994): "Consumer safety unit, home accidents death data in consumer safety", $19^{\text {th }}$ annual report, home accidents surveillance system, London, Department of Trade and Industry, pp. 45-75.

Hamza W S, (2000): "Epidemiology of accidents among children in a village in Assiut Governorate". Master Thesis public 
Health and Preventive Medicine, Faculty of Medicine, Assiut University.

Hassan F \& El-Sheikh E, (1996): "Surveillance of trauma in Port- Said", Egypt. CommMed-Dept. Faculty of Medicine Suez Canal University, Ismailia, Egypt.

Helmy F E, Labeeb S A, \& Shafie I F, (2002): "Assessment of home environmental risk factors regarding accidents among preschool children. Assiut University", Bulletin for environmental researchers: 5 (1), pp. 21-29.

Hitchcock J E, Schubert P E, \& Thomas S A, (1999): "Community health nursing, caring in action, an international Thomson publishing company", London, p. 388.

Hogg C, (1996): "Preventing children accidents: a guide for health. Authorities and boards", $\left(2^{\text {nd }}\right.$ ed.). London, child accident prevention trust, pp. 309-310.

Ibrahim A, (1991): "Assessment of knowledge, attitude and practice of mothers attending Cairo University Hospital toward home accidents among preschool children. Master Thesis in Nursing", Higher Institute of Nursing, Cairo University.

Ibrahim H H, (2004): "Investigative epidemiology of childhood accidents in ElFateh district", Assiut Governorate, Upper Egypt. Doctor Thesis, Faculty of Medicine, Assiut University.

Kamel M I, Hammam H M, El - Taiby H, \& Youaaif N, (2003): "Child injury prevention, final report, academy of scientific research and technology", Cairo.

Laffoy M, (1997): "Childhood accidents at home". Ir. Med. J. 1997. Jan. Feb, 90 (1): 26-27.

National safe kids campaign, (2000): "National SAFE KIDS Campaign promoting child safety to prevent unintentional injuries". www.safekids.org
Nossier S, Sherif A A, Mortuda M M, Dobbous N I, \& El-Shan F F, (1990): "A study of accidents among preschool children attending MCH centers in Alexandria". Alexandria J. of Pediatrics, (4): 45-48.

Robinson M J, \& Roberton D M, (2003) : "Practical pediatrics, $\left(5^{\text {th }}\right.$ ed.), Churchill Living Stone company", New York, p. 172.

Sadek H A \& Ahmed A A, (1986): "Some epidemiological features of 1 to 6 years old children suffering from accidental injuries and poisoning attending emergency department in Alexandria Hospital". Thesis for MPH, Faculty of Medicine, Alexandria University.

Sattin R, Rodriguez J, Devito C, \& Wingo P, (1998): "Home environmental hazards and the risk of fall injury events among community-dwelling older persons". Journal of American Geriatric Society, 46 (6): 669-676.

Shatanawi, M J, (1992): "Accidents among children under five years of age in Irbid Governorate", Jordan University for Science and Technology, Thesis.

Soori H \& Naghavi M, (1999): "Deaths from unintentional injuries in rural areas of the Islamic Republic of Iran". Eastern. Mediterranean Health Journal, 5(1): 5560. 33-Stanhope M \& Lancaster J, (1996). Community health nursing: promoting health of aggregates, families and individuals, $\left(4^{\text {th }}\right.$ ed.), Mosby, New York, pp. 570-580.

Walker V, (2002): "Child safety in your home". www.childsafety.com

Wong D L, Eaton M H, Winkelstein M L, Wilson D, Ahmann E, \& Thomas P, (1999): "Nursing care of infants and children, health promotion of the preschooler and family", ( $6^{\text {th }}$ ed. $)$. Mosby, New York, pp. 613-615, 694, 717. 


\section{تقييم معلومات وممارسات الأمهات نحو الحوادث المنزلية بيـن الأطفال تحت سن

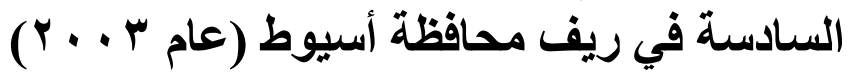

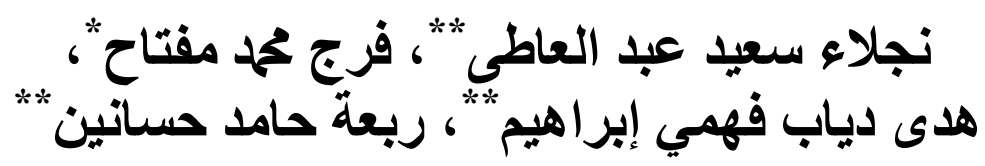

"قسم الصحة العامة - كلية الطب، **قسم تمريض صحة المجتمع - كلية التمريض - جامعة أسيوط

يتعرض الأطفال للخطر بنسبة عالية وذلك بسبب حب استطلاعهم الطبيعي ورغبتهم في تنفيذ مهارات جديدة، وأيضاً قدرة

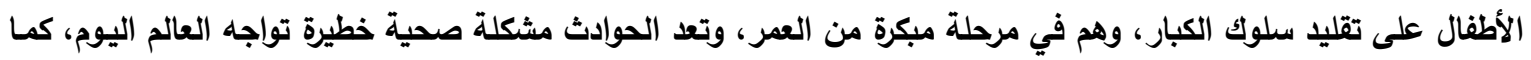
تعد من أكبر الأسباب في زيادة نسبة الوفيات بعد عمر عام واحد، وتعتبر تلك الحوادث من أهم أسباب دخول الهول المستشفي.

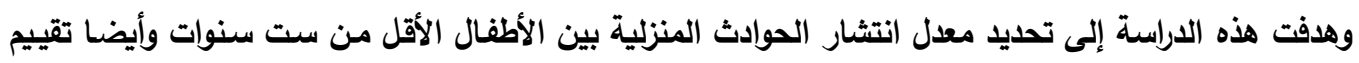

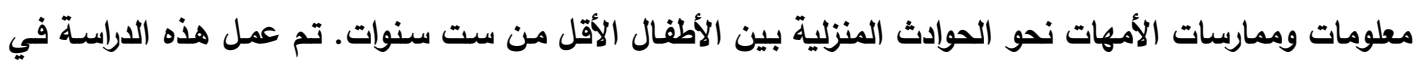

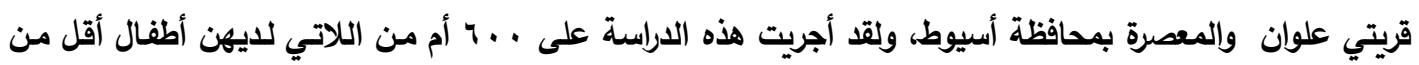

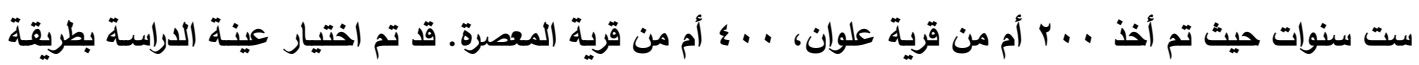

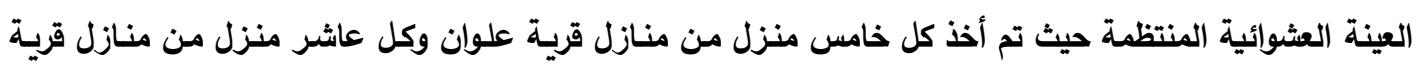

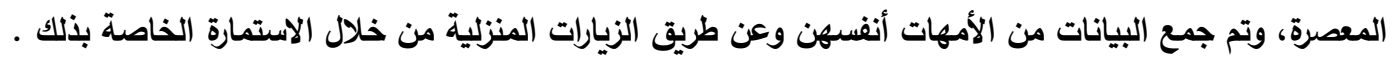

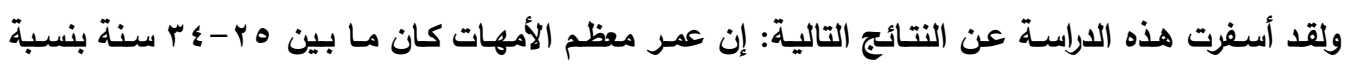

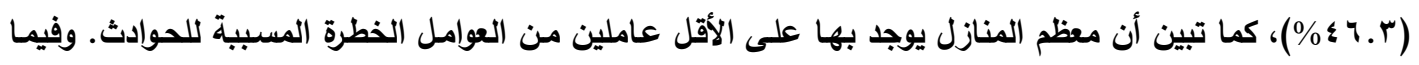

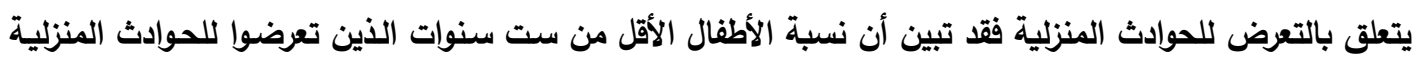

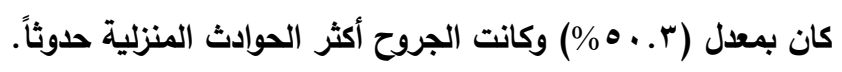

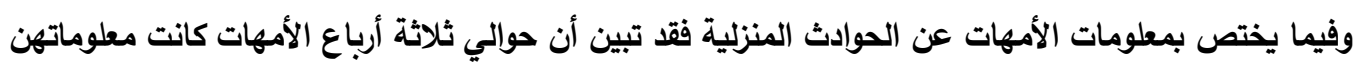

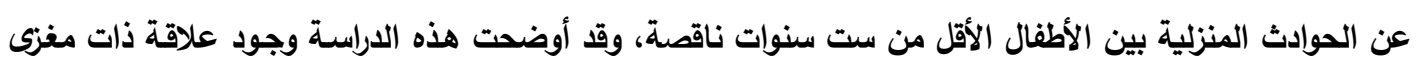
بين السن ومعلومات الأمهات، وبين التعليم ومعلومات الأمهات.

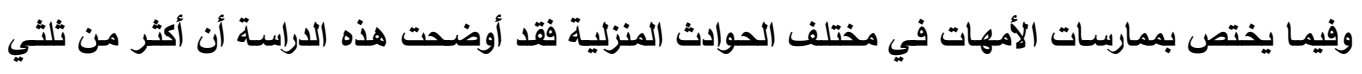

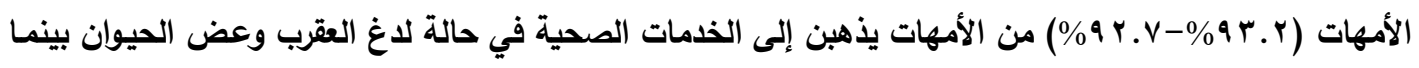

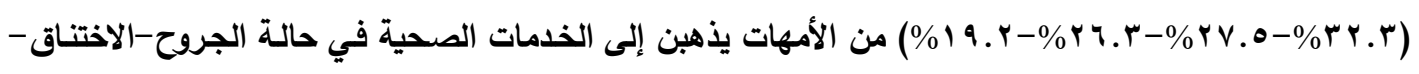

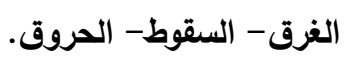

لذلك فقد أوصت هذه الدراسة على ضرورة تنفيذ فصول تثقيف صحي عن الحوادث للأمهات في مراكز رعاية

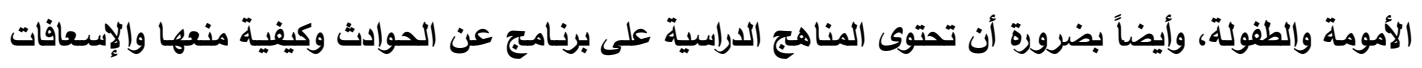

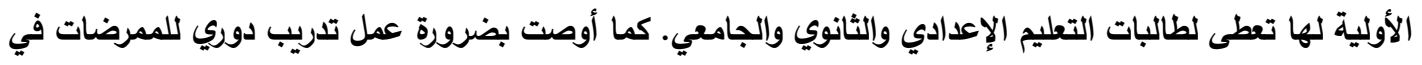
الوحدات الريفية عن الإسعافات الأولية وذلك لتنشيط مهارتهن. 